\title{
Hemigrammus arua, a new species of characid (Characiformes: Characidae) from the lower Amazon, Brazil
}

\author{
Flávio C. T. Lima ${ }^{1}$, Wolmar B. Wosiacki² and Cristiane S. Ramos ${ }^{2}$
}

A new Hemigrammus species is described from tributaries of the igarapé Juruti Grande and rio Arapiuns, lower rio Amazonas, Pará State, Brazil. The new species can be easily diagnosed from all its congeners, except from Hemigrammus stictus (Durbin), by possessing a single, large humeral spot which extends longitudinally from the fifth or sixth to the posterior margin of eighth to tenth, lateral line scales. It can be distinguished from Hemigrammus stictus by possessing a pronounced upper, anteriorlyoriented extension in the humeral blotch, conferring an inverted-comma shape to it, and by displaying a distinct life color pattern.

Uma nova espécie de Hemigrammus é descrita de afluentes do igarapé Juruti Grande e do rio Arapiuns, baixo rio Amazonas, Estado do Pará, Brasil. A nova espécie pode ser facilmente diagnosticada de todos seus congêneres, exceto Hemigrammus stictus (Durbin), por possuir uma única, grande mancha umeral que se estende da quinta ou sexta escamas à margem posterior da oitava à décima escama da linha lateral. Ela pode ser distinguida de Hemigrammus stictus por possuir uma extensão da mancha umeral pronunciada e anteriormente orientada, o que lhe confere uma forma de vírgula invertida e por possuir um padrão de colorido distinto em vida.

Key words: Hemigrammus stictus, Rio Arapiuns, Igarapé Juruti Grande, Lower Amazon, Humeral blotch.

\section{Introduction}

Among the Characidae currently assigned as "incertae sedis" within the family, Hemigrammus Gill is one of the most species-rich, with 49 species presently considered valid (Lima et al., 2003; Britski \& Lima, 2008; Marinho et al., 2008). None of the features used to diagnose Hemigrammus (i.e., five or more teeth on the inner premaxillary series, incompletely pored lateral line, and scaled caudal-fin basis) is unique to the genus. The last broad survey on the genus was published more than thirty years ago (Géry, 1977). Since then, there was a considerable increase in the number of known species in the genus (38 to the present 49) but no major treatment of its taxonomy. The phylogenetic relationships of Hemigrammus are, as most genera that were formerly assigned to the Tetragonopterinae (sensu Géry, 1977), poorly understood, and its purported monophyletic nature is also highly questionable. For example, Weitzman \& Palmer (1997: 225-226, 237) remarked that the type species of Hemigrammus, $H$. unilineatus, might be related to a putative monophyletic group within

${ }^{1}$ Museu de Zoologia da Universidade de São Paulo, Caixa Postal 42494, 04299-970 São Paulo, SP, Brazil. fctlima@usp.br ${ }^{2}$ Museu Paraense Emílio Goeldi, Caixa Postal 399, 66040-170 Belém, PA, Brazil. wolmar@museu-goeldi.br (WBW); crisramosbio@yahoo.com.br(CSR) 
Hyphessobrycon, the so-called "rosy tetra clade", which, if confirmed, would result in a drastic taxonomic rearrangement within Characidae.

During a broad biological survey conducted at Juruti municipality, a locality lying on the right bank of the rio Amazonas, slightly above the mouth of the rio Tapajós on the lower Amazon, a distinctive undescribed species of Hemigrammus was found. The aim of the present contribution is to describe this new species.

\section{Material and Methods}

Counts and measurements were taken according to Fink \& Weitzman (1974) and Menezes \& Weitzman (1990), except for counts of the horizontal scale rows below the lateral line that were counted to the pelvic-fin insertion. Horizontal scale rows between dorsal-fin origin and lateral line does not include scale of median predorsal series situated just anterior to first dorsal-fin ray. In the descriptions, the frequency of each count is given in parentheses after the respective count. An asterisk indicates counts of the holotype. Counts of supraneurals, vertebrae, procurrent caudal-fin rays, unbranched dorsal and anal fin rays, branchiostegal rays, gill-rakers, maxillary, and dentary teeth were taken only from cleared and stained paratypes (c\&s), prepared according to Taylor \& Van Dyke (1985). Vertebrae of the Weberian apparatus were counted as four elements and included in the vertebral counts, and the fused PU1+U1 of the caudal region as a single element. In the list of material examined, the number of whole specimens in the lot is followed by the number of those cleared and stained (if any). Jaw bones were cleaned from soft tissues for SEM images by a short (less than 10 minutes) immersion in weak (less than $1 \%$ ) sodium hypochlorite solution and after that air-dried. Institutional abbreviations follows Reis et al. (2003).

\section{Hemigrammus arua, new species}

Figs. 1-3

Holotype. MPEG 14755, 26.8 mm SL, Brazil, Pará State, município de Juruti, lago São Francisco do Alto Aruã, rio Aruã, tributary of rio Arapiuns, tributary of rio Tapajós, 02³6’4”S 5554'21”W, 20 Feb 2008, W. B. Wosiacki, R. D. O. Rayol \& A. S. Bezerra.

Paratypes. All from Brazil, Pará State, município de Juruti: MPEG 14756, 4, 20.3-26.3 mm SL, same data as holotype. MPEG 14757,138 (29, 14.7-30.0 mm SL), 5 c\&s, 16.4-22.0 mm SL; INPA 28979, 5, 15.6-21.4 mm SL; ANSP 187426, 5, 17.2-21.2 mm SL: same locality as holotype, 12 Aug 2004, W. B. Wosiacki \& A. S. Bezerra. MPEG 14758, 1, 19.6 mm SL, headwaters of igarapé Juruti Grande, right tributary of rio Amazonas, 02³4'30”S 56 24'12”W, 05 Aug. 2004, W. B. Wosiacki \& A. S. Bezerra. MPEG 14759, 2, 17.3-19.2 mm SL, rio Branco, tributary of rio Arapiuns, tributary of rio Tapajós, $02^{\circ} 20$ '58”S 5601'22”W, 10 Aug 2004, W. B. Wosiacki \& A. S. Bezerra. MPEG 14760, 10, 18.0-21.8 mm SL, same locality and collectors as MPEG 14759, 11 Aug 2004. MPEG 14761, 3, 17.3-21.3 mm SL, same locality and collectors as MPEG 14759, 09 Aug 2004. MZUSP 100379, 29, 13.8-24.7, 3 c\&s, 17.2-19.5 mm SL, igarapé São Francisco do Alto Aruã, 02²0’54”'S 560'42”'W, 11 Aug 2004, W. B. Wosiacki.

Diagnosis. Hemigrammus arua can be diagnosed from all congeners, except $H$. stictus (Durbin), by possessing a large, single humeral spot which is situated from fifth-sixth to posterior margin of eighth-tenth lateral line scales ( $v s$. humeral spot absent, double, or, if single, situated from second-third to posterior margin of fourth-fifth lateral line scales). Hemigrammus arua can be distinguished from $H$. stictus by

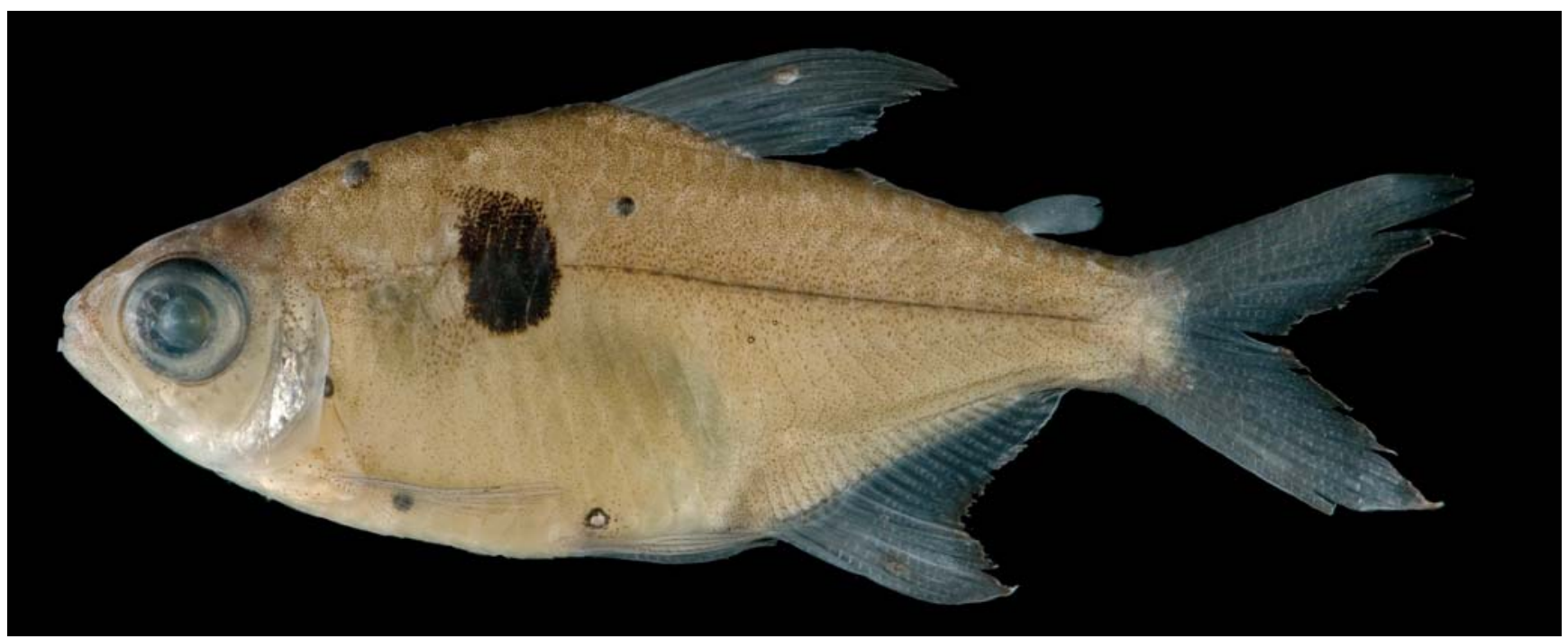

Fig. 1. Hemigrammus arua, holotype, MPEG 14755, 26.8 mm SL: Brazil, Pará State, município de Juruti, lago São Francisco do Alto Aruã. Black spots over body and fins are nematodes’ cysts. 


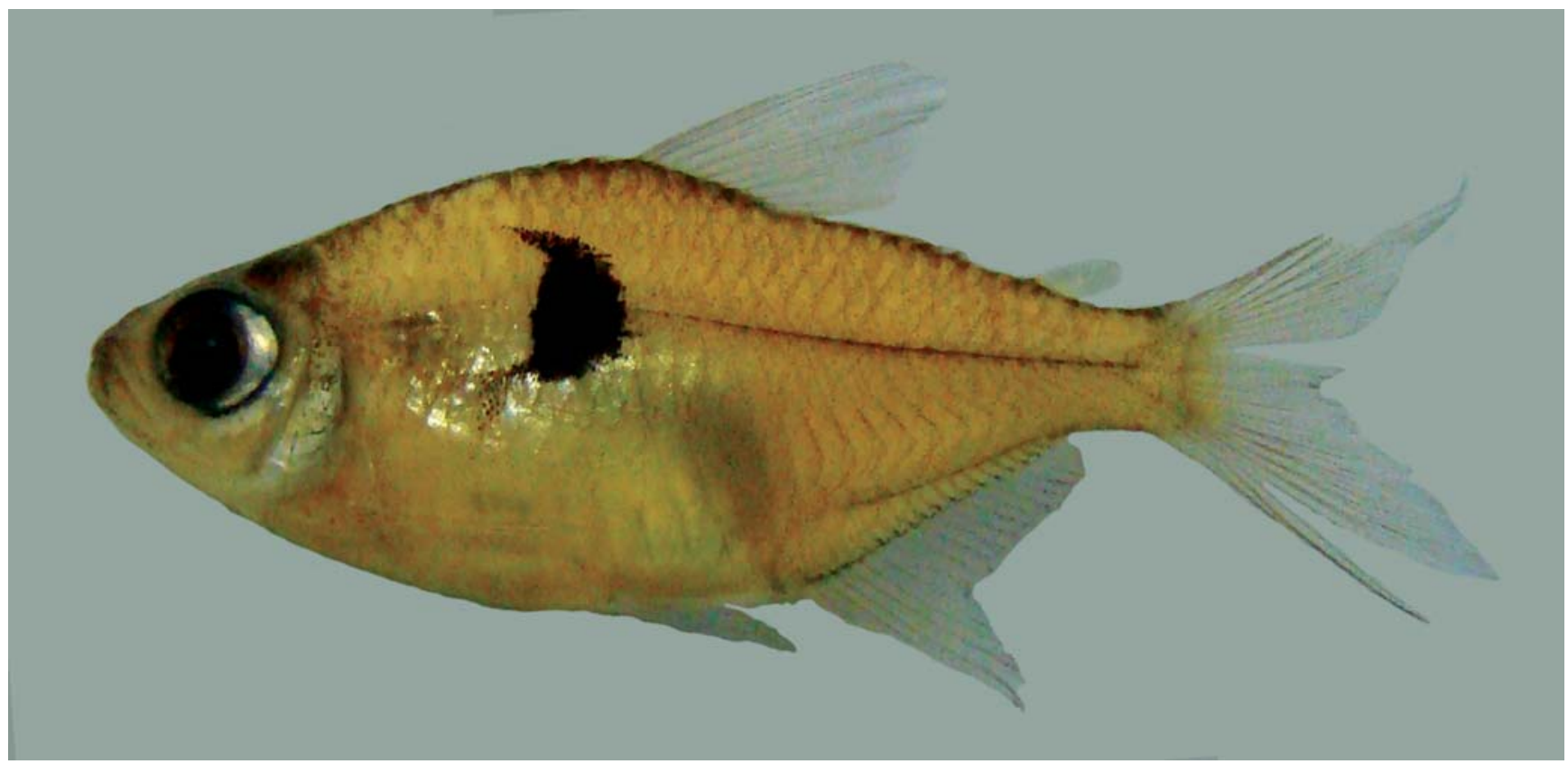

Fig. 2. Hemigrammus arua, paratype, MPEG 14757, 25.4 mm SL: Brazil, Pará State, município de Juruti, lago São Francisco do Alto Aruã.

possessing a humeral spot roughly rectangular, higher than wide, with a pronounced upper, anteriorly-oriented extension, conferring an inverted-comma shape to the blotch (vs. humeral spot roughly rounded, not presenting an inverted-comma shape), and life color pattern presenting unpaired fins orangereddish (vs. caudal fin and caudal peduncle bright red in life, remaining fins translucent).

Description. Morphometric data of holotype and paratypes presented in Table 1. Body compressed, moderately high. Greatest body depth at dorsal-fin origin. Dorsal profile of head convex from upper lip to vertical through middle of orbit; slightly concave from latter point to tip of supraoccipital spine. Predorsal profile of body convex, posteroventrally inclined along dorsal-fin base. Body profile straight to slightly convex from dorsal-fin base terminus to adipose fin; slightly concave between latter point to origin of anteriormost procurrent caudal-fin ray. Ventral profile of head and body convex from lower lip to anal-fin origin, sometimes slightly concave at urogenital opening. Body profile along anal-fin base straight and posterodorsally inclined. Ventral profile of caudal peduncle slightly concave.

Jaws equal, mouth terminal. Posterior tip of maxilla reaching vertical through anterior third of orbit. Premaxillary teeth in two rows (Fig. 4). Outer row with 2(1), 3*(25) 4(3), or 5(2) relatively compressed, tri- to tetracuspidated, elongated teeth. Inner row with $5^{*}(27), 6(4)$, or 7(1) relatively compressed, penta- to heptacuspidated teeth. Maxilla with 4(2), 5(1), or 6(4) tri- to pentacuspidated teeth. Anteriormost teeth larger. Dentary with 12(1), 13(2), 14 (1), 15(1), 16(1), or 17(1) teeth, sixth to seventh anteriormost teeth larger, relatively compressed, penta- to heptacuspidated, gradually decreasing in size. Remaining dentary teeth considerably smaller, cylindrical, uni- to tricuspidated.

Scales cycloid, with few slightly divergent radii extending to posterior margin of scales. Lateral line slightly decurved ventrally, incompletely pored, with $6 *(10), 7(8), 8(8)$, or 9(1) perforated scales. Lateral series scales including lateral line scales 24(1), 25(2), 26(1), 27(6), 28(9), 29(4), or 30*(5). Horizontal scale rows between dorsal-fin origin and lateral line typically $5^{*}$, a single specimen with six. Horizontal scale rows between lateral line and pelvic-fin insertion three. Scales along middorsal line between distal tip of supraoccipital process and origin of dorsal fin 7(2), 8(26), or 9*(1). Horizontal scale rows around caudal peduncle 10(1), 11(8), or 12*(19). Single row of 3-4 scales covering base of anteriormost anal-fin rays. Caudal fin scaled, basalmost scales slightly smaller than caudal peduncle scales. Scales present on basal third of upper and lower caudal lobes (lost in most specimens).

Dorsal-fin rays ii, 9*(28), 10(1), not including small ossification anterior to first unbranched ray, discernible only in c\&s specimens, absent in two out of eight c\&s individuals. Dorsal fin pointed in juvenile specimens, and rounded in adult specimens (see Fig. 3), last unbranched and four anteriormost branched rays considerably more elongated than remaining rays. Dorsal-fin origin slightly anterior to vertical through middle of standard length. Base of posteriormost dorsal-fin ray at vertical through anal-fin origin. First dorsal-fin pterygiophore inserting posterior to neural spine of $8^{\text {th }}(8)$ vertebrae. Adipose fin present. Anal-fin rays iv(8), 17(2), $18 *(3), 19(14), 20(8)$, or 21(1). Anteriormost anal-fin pterygiophore inserting behind haemal spine of $15^{\text {th }}(2)$ or 


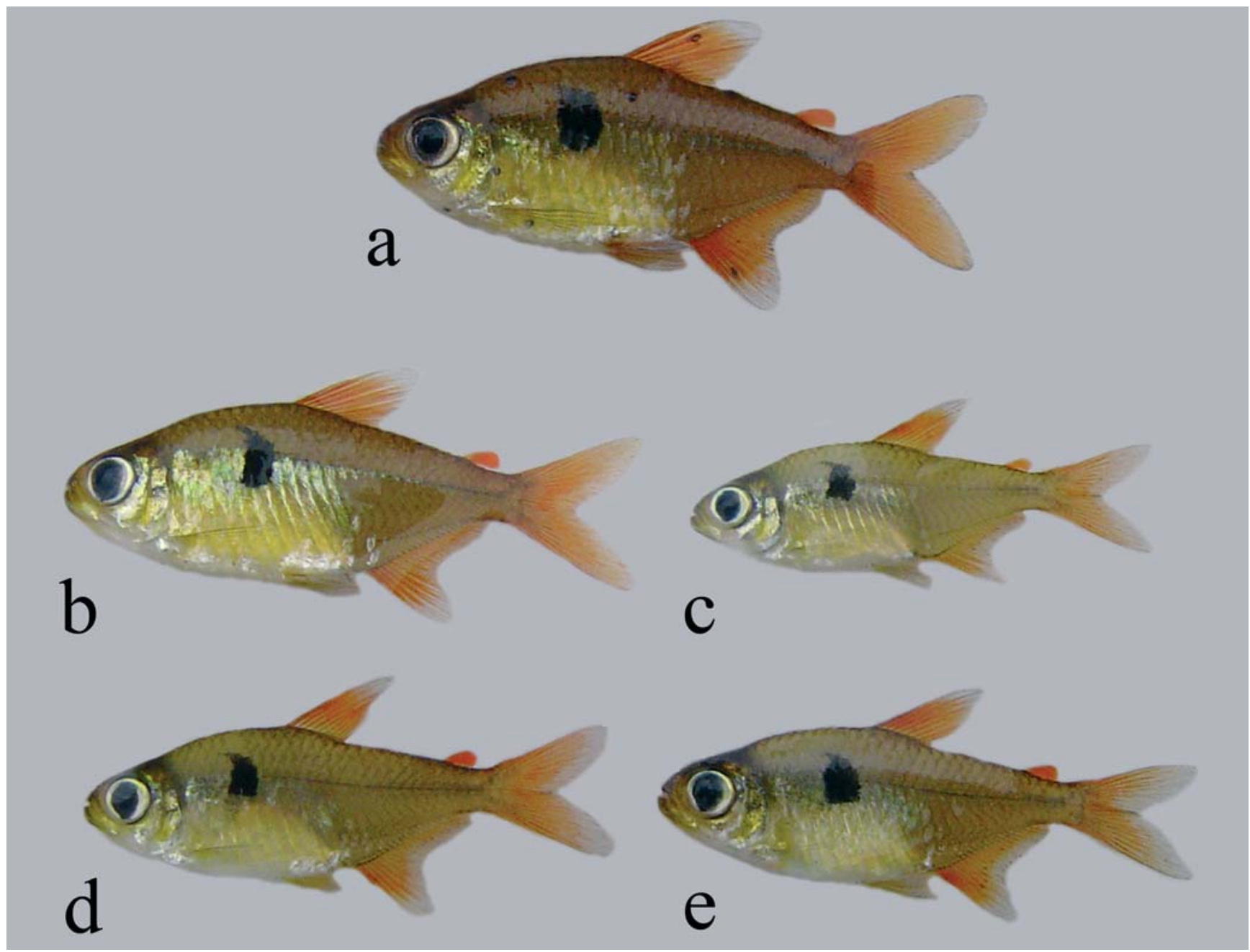

Fig. 3. Hemigrammus arua, a) holotype, MPEG 14755, 26.8 mm SL, and b-e, paratypes, MPEG 14756 (20.3-26.3 mm SL); immediately after collecting. Black spots over body and fins are nematodes' cysts.

$16^{\text {th}}(6)$ vertebrae. Pectoral-fin rays i, 9(6), 10*(20), 11(3). Tip of pectoral fin reaching vertical through pelvic-fin insertion. Pelvic-fin rays typically i,7*, a single specimen i,8. Caudal fin forked, lobes slightly rounded, similar in size. Principal caudalfin rays $10+9$. Dorsal procurrent caudal-fin rays $8(2), 9(5)$, or $10(1)$, and ventral procurrent caudal-fin rays 6(2), 7(5), or 8(1). First gill arch with 0(1), 1(1), or 2(2) hypobranchial, 6(1), 8(1), 9(2) ceratobranchial, 1(4) on cartilage between ceratobranchial and epibranchial, and 4(1), 5(1), or 6(2) epibranchial gill-rakers. Vertebrae 31(8). Supraneurals 3(1) or 4(7). Branchiostegal rays four; three branchiostegal rays originating from anterior ceratohyal and one from posterior ceratohyal.

Color in alcohol. Ground color tan, slightly darker dorsally. Guanine pigmentation present on opercular and infraorbital bones. Lower lip, snout, and top of head densely covered by small dark chromatophores, resulting in overall dark pigmentation. Upper half of opercle and fifth infraorbital with large, scattered dark chromatophores. Anterior two-thirds of eye dark pigmented. Gular area clear to tan.

Mid-dorsal and dorsal portion of first lateral scale rows with dense concentration of dark chromatophores, concentrated mainly on scale margins. Large, distinctive blotch, situated immediately above lateral line scales row, extending longitudinally from the fifth or sixth to the posterior margin of eighth to tenth lateral-line scales. Blotch roughly rectangular, higher than wide, with a pronounced upper, anteriorly-oriented extension, giving an invertedcomma shape to the blotch. Thin, subjacent dark midlateral stripe, extending along midline from blotch terminus to anterior portion of caudal peduncle. Scales of dorsal and lateral surfaces of body possessing numerous dark chromatophores, especially over midline. Subjacent dark chromatophores forming thin lines over myomere margins above anal fin base. Scales on abdominal region with few dark chromatophores. Narrow, subjacent stripe of dark pigment located dorsal to anal-fin base, extending approximately along region where hypaxial musculature and 
Table 1. Morphometric data of holotype and paratypes of Hemigrammus arua. Standard length (SL) is expressed in mm, all other measurements are expressed as percentages of SL, except for subunits of head that are expressed as percentages of head length (HL). N includes holotype.

\begin{tabular}{lccccc}
\hline \multicolumn{1}{c}{ Holotype } & Min. & Max. & Mean & $\mathrm{N}$ \\
\hline Standard length (mm) & 26.8 & 23.0 & 30.0 & 25.1 & 34 \\
\cline { 2 - 6 } & Percents of standard length & & & \\
Greatest body depth & 41.4 & 33.0 & 43.6 & 39.9 & 34 \\
Snout to dorsal-fin origin & 54.9 & 50.8 & 54.9 & 52.6 & 34 \\
Snout to pectoral-fin origin & 29.9 & 26.2 & 32.5 & 28.4 & 34 \\
Snout to pelvic-fin origin & 50.4 & 49.0 & 54.7 & 51.3 & 34 \\
Snout to anal-fin origin & 67.9 & 64.3 & 70.9 & 67.3 & 33 \\
Caudal peduncle depth & 12.3 & 8.4 & 12.3 & 10.6 & 34 \\
Caudal peduncle length & 9.7 & 9.1 & 15.1 & 11.9 & 33 \\
Pectoral-fin length & 21.6 & 15.4 & 23.6 & 21.0 & 34 \\
Pelvic-fin length & 18.3 & 16.5 & 20.7 & 18.8 & 33 \\
Dorsal-fin base length & 14.2 & 12.3 & 17.4 & 15.1 & 34 \\
Dorsal-fin heigth & 27.2 & 20.1 & 33.6 & 29.5 & 34 \\
Anal-fin base length & 29.5 & 23.6 & 31.7 & 27.4 & 34 \\
Anal-fin lobe length & 22.4 & 17.7 & 25.1 & 22.1 & 34 \\
Eye to dorsal-fin origin & 39.6 & 36.6 & 40.5 & 38.1 & 34 \\
Dorsal-fin origin to caudal-fin base & 53.7 & 48.7 & 56.7 & 53.7 & 34 \\
Bony head length & 24.3 & 22.4 & 28.7 & 26.1 & 34 \\
& Percents of head length & & & \\
Horizontal eye diameter & 52.3 & 38.5 & 52.3 & 43.7 & 34 \\
Snout length & 33.8 & 15.4 & 35.8 & 21.4 & 34 \\
Least interorbital width & 40.0 & 31.4 & 45.5 & 36.8 & 34 \\
Upper jaw length & 49.2 & 35.4 & 50.9 & 43.3 & 34 \\
\hline
\end{tabular}

muscles of anal fin meet, sub-parallel to anal-fin base. Dark, subjacent pigmentation at base of anal-fin rays, forming a thin longitudinal line. Outer caudal-fin rays with margins dark pigmented, branched rays with few dark chromatophores along dorsal and ventral margins. Inner caudal-fin rays with distal portion more pigmented than remaining fin. Anal-fin rays with scattered chromatophores on interradial membranes. Dorsal, pectoral and pelvic-fin rays with dark pigment along anterior and posterior margins. Adipose fin with scattered dark chromatophores.

Life coloration. Based on a photograph of the holotype (MPEG 14755) and paratypes (MPEG 14756), taken immediatelly after fixation (Fig. 3). Overall ground color brown. Opercular area, facial bones, and abdominal area above pectoral-fin basis bright golden, with a greenish hue. Gular and ventral area below pectoral-fin basis silvery. Dorsal, adipose, caudal, and anal fins, intense orange-reddish, except for their relatively faded distal portions. Pelvic fins yellowish, except in the holotype, which possess orange-reddish pelvic fins. Pectoral fins translucent.

Sexual dimorphism. Not detected. Bony hooks on anal and pelvic fins of mature males, a common dimorphic feature among characids (Malabarba \& Weitzman, 2003) were not found.

Geographical distribution. Known from the headwaters of the rio Arapiuns (rio Branco and rio Aruã), rio Tapajós basin,

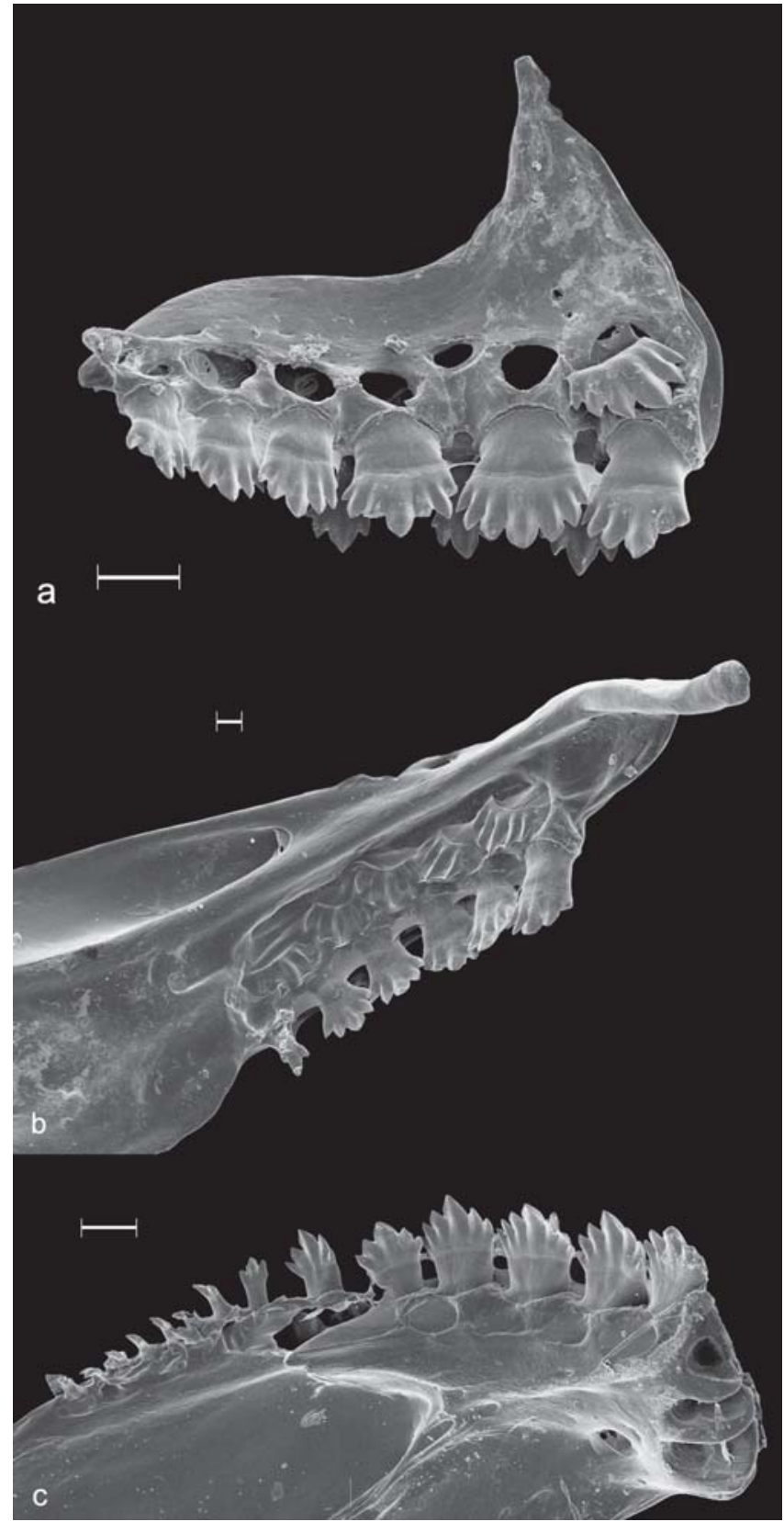

Fig. 4. Hemigrammus arua, paratype, MZUSP 100379, 19.5 mm SL; scanning electron micrographs (SEM) showing left premaxillary (a), maxillary (b), and dentary teeth (c) in mesial view. Scale bar: (a-c): $100 \mu \mathrm{m}$; (b) $30 \mu \mathrm{m}$.

and from the adjacent headwaters of the igarapé Juruti Grande, a right margin tributary of the rio Amazonas, Pará State, Brazil (Fig. 5).

Ecological notes. The type locality, lago São Francisco do Alto Aruã, is, in spite of its name, not a lake but actually a large river pool (about 200 meters wide). Satellite images of the area suggest that this portion of the rio Aruã is a valley of an ancient ria-lake which is being filled by sediments, as evidenced by the presence of extensive floodplains upstream 


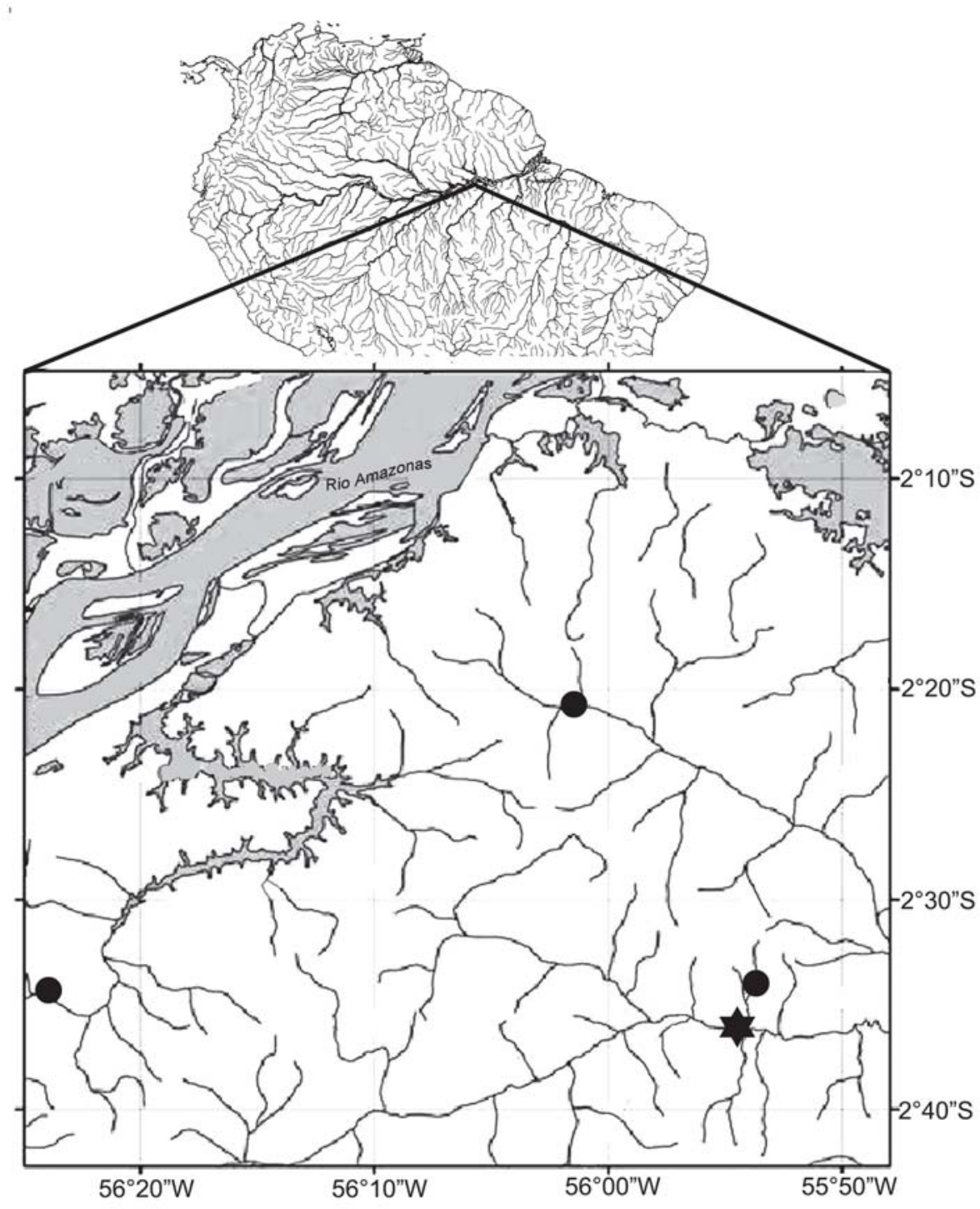

Fig. 5. Map of northern South America, showing (inset) the surroundings of Juruti, Pará State, Brazil, and sites of collection of Hemigrammus arua (dots). Star: Type locality.

the lake Aruã (see Klammer, 1984, for a discussion on this type of landscape feature in the Central Amazon region). Specimens of Hemigrammus arua were collected in relatively shallow (1-1.5 meters deep) marginal areas, with abundant aquatic macrophytes, both emergent and non-emergent. Identifiable itens found in gut contents of four specimens (MPEG 14757. 22.0-27.7 mm SL) were insect larvae (both aquatical and terrestrial forms), winged insects, and vegetal remains.

Etymology. Arua, after lago São Francisco do Alto Aruã, the type locality. A noun in apposition.

\section{Discussion}

Hemigrammus arua is herein assigned to this genus based on the possession of the features used to diagnose it (i.e., five or more teeth on the inner premaxillary series, incompletely pored lateral line, and scaled caudal-fin basis). As noticed in the Introduction, the relationships within Characidae, and particularly among many of the genera formerly assigned to the Tetragonopterinae and currently considered incertae sedis in the family (see Lima et al., 2003), are poorly known. The distinction of Hemigrammus from several related genera is based in a single character state, e.g., the naked caudal-fin 
basis in Hyphessobrycon, the completely pored lateral line in Moenkhausia, the high number of maxillary teeth in Parapristella, the absence of the outer row of premaxillary teeth in Petitella, the absence of adipose fin in Hasemania, or the elongated lower caudal-fin lobe in Thayeria. The typological definitions of these and another genera formerly assigned to the subfamily Tetragonopterinae (sensu Géry, 1977) were heavily criticized by Weitzman \& Fink (1983), but unfortunately, our knowledge of the relationships of these genera have not advanced substantially ever since. As a result, the monophyly of Hemigrammus remains doubtful, and the intrarrelationships within the genus are still unknown. The only attempt to delimit groups within Hemigrammus, though admittedly artificial ones, was by Géry (1977: 490). This author, based on Ellis (in Eigenmann, 1918), split Hemigrammus into five groups, based on color pattern. Hemigrammus arua fit the group "b" from Géry (1977), the so-called Hemigrammus bellottii group, which includes species possessing a humeral spot but lacking a caudal peduncle spot. Among the species included in that group, Hemigrammus arua resembles more closely H. stictus, with which it shares a humeral spot situated posteriorly than the usual condition in most characids. The humeral spot in characids generally lies over the second to the third, and extends from the fourth to the fifth, lateral line scales. In contrast, Hemigrammus arua and $H$. stictus possess a humeral spot lying over the fifth to the sixth, and extending longitudinally into the eighth to the tenth, lateral line scales. A similar, putatively non-homologous condition, is only found, among the Characidae formerly assembled under the subfamily Tetragonopterinae, in Jupiaba polylepis (Günther), which possess a humeral spot lying over the sixth, and extending to the ninth, lateral line scales (Zanata, 1997). This "dislodged" humeral spot lies at the same position of the second humeral spot in the Hemigrammus species that possess that feature (e.g., H. ocellifer). We suggest that the dislodged humeral spot of Hemigrammus arua and H. stictus might be homologous to the second humeral spot found in some other Hemigrammus species, the condition displayed by these species having evolved through the loss of the first, more anterior, humeral spot.

Hemigrammus arua was collected in an area of terra firme near the extensive floodplain areas of the lower rio Amazonas. Other fish species recently described from the same general area are Apistogramma arua Römer \& Warzel and Acestridium triplax Rodríguez \& Reis. We are aware of at least two more undescribed fish species, both belonging to the genus Hyphessobrycon, occurring in the area. Due to the difficulty to reach terra firme areas, this type of habitat is comparatively much less sampled than floodplain and main channel riverine habitats. Vast expanses of terra firme habitats across central and western Amazon basin remain to be explored ichthyologically, and it is expected that much of the future ichthyological discoveries in the area will be concentrated in this type of habitat.

Comparative material examined. Jupiaba polylepis: MPEG 7080,
238, 26.2-54.6 mm SL, Brazil, Pará State, rio Xingu basin. MPEG 7802, 8, 50.5-59.2 mm SL, Brazil, Pará State, rio Tapajós basin. Hemigrammus ocellifer: MPEG 13158,15, 21.3-30.3 mm SL, Brazil, Amazonas State, rio Urucu. MZUSP 17409, 84, 20.6-35.7 mm SL, Brazil, Amazonas State, rio Solimões. Hemigrammus cf. pretoensis: MZUSP 17627, 6, 39.5-51.7 mm SL, Brazil, Amazonas State, rio Solimões. Hemigrammus stictus: MPEG 14762, 32, 20.4-38.0 mm SL, Brazil, Pará State, rio Araticum. MPEG 6861, 24.7 mm SL, Brasil, Pará State, rio Paru. MZUSP 57490, 233, 16.9-30.7 mm SL, Brazil, Amazonas State, rio Negro. MZUSP 7789, 12, 29.1-33.1 mm SL, Brazil, Amazonas State, rio Amazonas. MZUSP 95269, 83, 27.2-39.0 mm SL, Brazil, Amazonas State, rio Negro.

\section{Acknowledgements}

Type material of Hemigrammus arua was collected during a biological survey financed by Alcoa Alumínio S/A (agreement Alcoa/MPEG/FIDESA). For help during fieldwork, we thank Luciano F. A. Montag, Alberto Bezerra, Roberta D. Silva, and Arthur B. Araújo. Gláucia Machado (MPEG) kindly identified the gut contents. Lara G. Passos (MZUSP) helped with SEM images. Eduardo G. Baena prepared Fig. 1 and edited Fig. 4. Travels to Belém by the first author were funded by the Programa de Pesquisa em Biodiversidade (PPBIO) from the Ministério da Ciência e Tecnologia (MCT), Brazilian government, and Programa Calha-norte (Conservation International, Brazil/MPEG/Sema). The senior author was funded by FAPESP (grant 07/02978-7).

\section{Literature Cited}

Britski, H. A. \& F. C. T. Lima. 2008. A new species of Hemigrammus from the upper rio Tapajós basin in Brazil (Teleostei: Characiformes: Characidae). Copeia, 2008(3): 565-569.

Eigenmann, C. H. 1918. The American Characidae [Part 2]. Memoirs of the Museum of Comparative Zoology, (2): 103-208.

Fink, W. L. \& S. H. Weitzman. 1974. The so-called cheirodontin fishes of Central America with description of two new species (Pisces: Characidae). Smithsonian Contributions to Zoology, 172: 1-46.

Géry, J. 1977. Characoids of the world. New Jersey, T.F.H. Publications, 672p.

Klammer, G. 1984. The relief of the extra-Andean Amazon basin. Pp. 47-84. In: H. Sioli (Ed.). The Amazon: limnology and landscape ecology of a mighty tropical river and its basin. Dordrecht, Junk, 749p.

Lima, F. C. T., L. R. Malabarba, P. A. Buckup, J. F. P. da Silva, R. P. Vari, A. Harold, R. C. Benine, O. T. Oyakawa, C. S. Pavanelli, N. A. Menezes, C. A. S. Lucena, R. E. Reis, F. Langeani, L. Casatti, V. A. Bertaco, C. R. Moreira \& P. H. F. Lucinda. 2003. Genera incertae sedis in Characidae. Pp. 106-169. In: Reis, R. E., S. O. Kullander \& C. J. Ferraris (Eds.). Check list of the freshwater fishes of South and Central America. Porto Alegre, Edipucrs, 729p.

Malabarba, L. R. \& S. H. Weitzman. 2003. Description of a new genus with six new species from Southern Brazil, Uruguay and Argentina, with a discussion of a putative characid clade (Teleostei: Characiformes: Characidae). Comunicações do Museu de Ciências e Tecnologia da PUCRS, Série Zoologia, 16: 67-151. 
Marinho, M. M. F., F. R. Carvalho, F. Langeani \& F. L. Tatsumi. 2008. A new Hemigrammus Gill from upper rio Paraná system, southeastern Brazil (Characiformes: Characidae). Zootaxa, 1724: 52-60.

Menezes, N. A. \& S. H. Weitzman. 1990. Two new species of Mimagoniates (Teleostei: Characidae: Glandulocaudinae), their phylogeny and biogeography and a key to the glandulocaudin fishes of Brazil and Paraguay. Proceedings of the Biological Society of Washington, 103: 380-426.

Reis, R. E., S. O. Kullander \& C. J. Ferraris Jr. (Eds.). 2003. Checklist of the freshwater fishes of South and Central America. Edipucrs, Porto Alegre, 729p.

Taylor, W. R. \& G. C. Van Dyke. 1985. Revised procedures for staining and clearing small fishes and other vertebrates for bone and cartilage study. Cybium, 9: 107-109.

Weitzman, S. H. \& W. L. Fink. 1983. Relationships of the neon tetras, a group of South American freshwater fishes (Teleostei, Characidae), with comments on the phylogeny of New World characiforms. Bulletin of the Museum of Comparative Zoology, 150(6): 339-395.

Weitzman, S. H. \& L. Palmer. 1997. A new species of Hyphessobrycon (Teleostei: Characidae) from the Neblina region of Venezuela and Brazil, with comments on the putative 'rosy tetra clade'. Ichthyological Exploration of Freshwaters, 7(3): 209-242.

Zanata, A. M. 1997. Jupiaba, um novo gênero de Tetragonopterinae com osso pélvico em forma de espinho (Characidae, Characiformes). Iheringia, série Zoologia, 83: 99-136.

Accepted April 2009

Published June 17, 2009 